\title{
Assessment of Seasonal Variability of Cytochemical Responses to Contaminant Exposure in the Blue Mussel Mytilus edulis (Complex)
}

\author{
A. N. Kagley, ${ }^{1}$ R. G. Snider, ${ }^{1}$ P. K. Krishnakumar, ${ }^{2}$ E. Casillas $^{3}$ \\ ${ }^{1}$ Environmental Conservation Division, Northwest Fisheries Science Center, National Marine Fisheries Service, National Oceanic and Atmospheric \\ Administration, Hatfield Marine Science Center, 2030 S. Marine Science Dr., Newport, Oregon 97391, USA \\ ${ }^{2}$ Research Centre, Central Marine Fisheries Research Institute, P.B. No 244, Bolar, Mangalore 575 001, India \\ 3 Environmental Conservation Division, Northwest Fisheries Science Center, National Marine Fisheries Service, National Oceanic and Atmospheric \\ Administration, 2725 Montlake Blvd. E., Seattle, Washington 98112, USA
}

Received: 16 December 2001/Accepted: 30 May 2002

\begin{abstract}
A selected suite of cytochemical parameters in Mytilus edulis are altered in response to field and laboratory exposure to chemical contaminants. These biomarkers include lysosomal stability, nicotinamide adenine dinucleotide phosphate (NADPH)-ferrihemoprotein reductase activity, liposfuscin deposition, and accumulation of lysosomal and cytoplasmic unsaturated neutral lipid. Normal variations in physiological processes (influenced by exogenous seasonal changes in temperature, salinity, food availability, etc.) may alter the sensitivity of these biomarkers to contaminant exposure. To address this issue, M. edulis (complex) were sampled monthly from a reference nonurban site (Coupeville, Penn Cove) and a polluted urban site (Seacrest, Elliott Bay) in Puget Sound, WA, for a period of 15 months. Physiological measurements including total length, total weight, somatic and mantle weights (an indication of gonadal development and reproductive status), condition index, and the presence or absence of hemic neoplasia (HN, or leukemia) were recorded. Significant differences in lysosomal stability, lysosomal and cytoplasmic unsaturated neutral lipids, lipofuscin deposition, and NADPH-ferrihemoprotein reductase activity in cells of the digestive gland or digestive tubules were generally found in mussels taken throughout the year from Seacrest compared to mussels sampled from Coupeville, consistent with exposure to chemical contaminants. No seasonally influenced suppression of the entire suite of parameters as measures of contaminant exposure was evident. Therefore these biomarkers can be used to evaluate contaminant exposure in mussels throughout the entire year.
\end{abstract}

Marine bivalves, including the blue mussel (Mytilus edulis complex), are widely used in urban marine habitats to monitor levels of chemical contaminants (e.g., O'Connor 1992; Gold-

Correspondence to: A. Kagley; email: anna.kagley@noaa.gov berg et al. 1983; Farrington et al. 1983; Lauenstein 1988, 1995; Lauenstein and Dolvin 1992). Mussels are chosen as indicators because they are sessile filter feeders and can bioaccumulate high levels of contaminants (Livingston 1991; O'Connor and Lauenstein 1989; Pruell et al. 1987) in the digestive gland and surrounding tissues. The digestive gland (or digestive tubules) is the primary location of digestion and absorption of nutrients in mussels and is typically a site of high contaminant accumulation. Accumulation of contaminants can induce changes in a wide range of physiological and cytochemical parameters in the digestive gland (Bayne et al. 1988; Bayne 1989; Gray 1992; Krishnakumar et al. 1995). These laboratory and field studies show not only that exposure to chemical contaminants have biological consequences but moreover that these physiological responses may serve as indicators of contaminant exposure.

A study by Porte et al. (1991) showed that in mussels exposed to chemical contaminants in the field, biological and cytochemical measurements of the detoxifying enzymes present in the digestive cells can serve as indicators of chemical contaminant exposure. Laboratory studies confirm that lysosomal responses in the digestive cells show strong associations to contaminant exposure (Lowe et al. 1981; Moore and Clark 1982; Moore et al. 1985; Pipe and Moore 1986; Nott and Moore 1987; Axiak et al. 1988; Moore 1988, 1991; Cajaraville et al. 1989; Krishnakumar et al. 1990; Winston et al. 1991; Viarengo et al. 1992). Parameters that were consistently indicative of contaminant exposure included lysosomal stability, nicotinamide adenine dinucleotide phosphate (NADPH)-ferrihemoprotein reductase activity, lipofuscin deposition, and accumulation of lysosomal and cytoplasmic unsaturated neutral lipid.

These cytochemical responses were measured previously in mussels from various areas of Puget Sound, Washington (Krishnakumar et al. 1995). High levels of chemical pollutants, including polycyclic aromatic hydrocarbons (PAHs) and polychlorinated biphenyls (PCBs), are found in sediments and biota at several of these locations (NOAA 1989; Stein et al. 1992). Krishnakumar et al. (1997) subsequently found in laboratory 


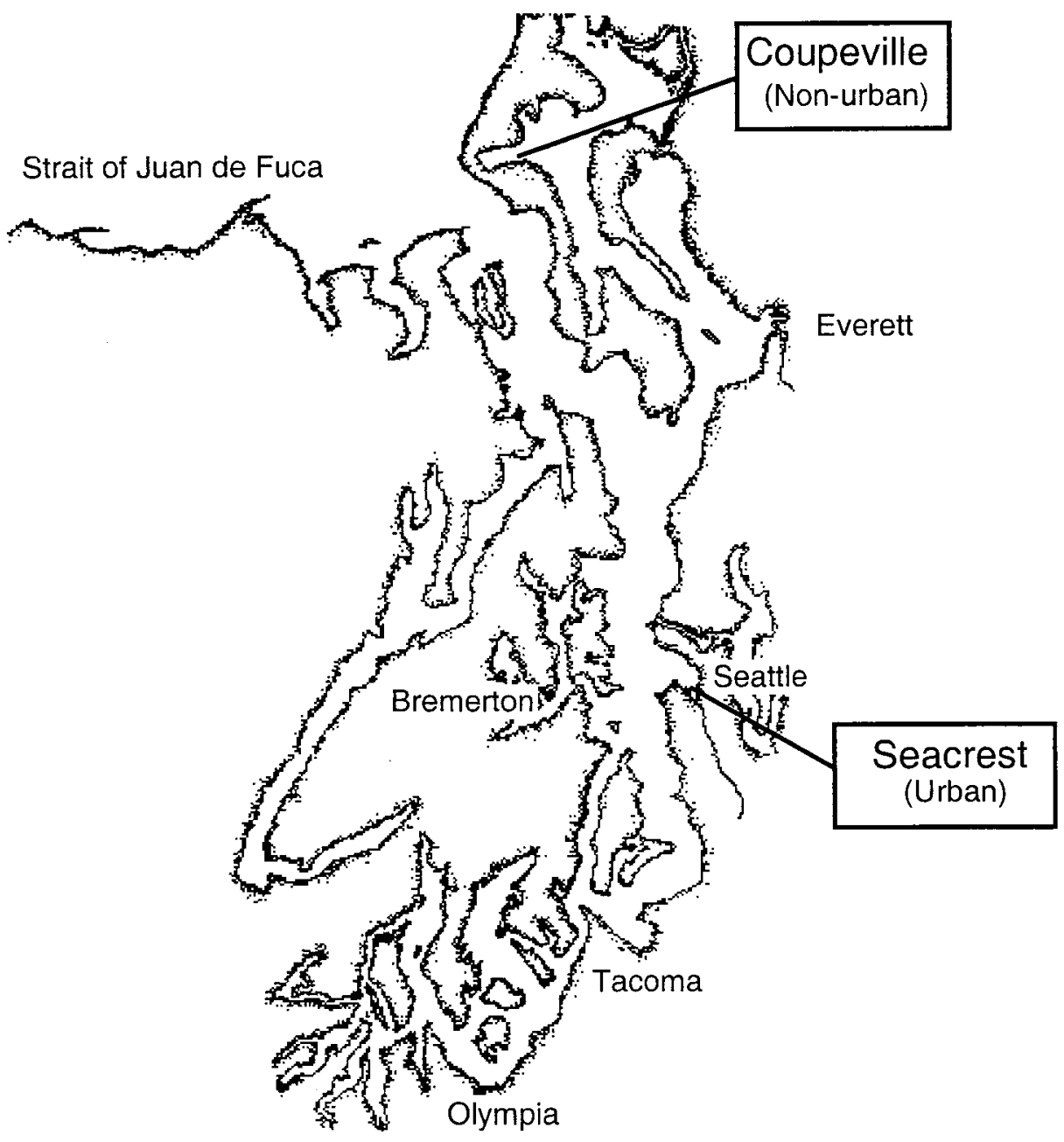

Fig. 1. Map of Puget Sound, WA, showing the two collection sites. Coupeville, on Whidbey Island, is the nonurban reference site and Seacrest, on Elliott Bay, is the urban polluted site studies that mussels had similar cytochemical responses to both PAHs and PCBs. Collectively, these studies not only suggest that cytochemical responses have the potential to serve as biomarkers of stress but also serve specifically as biological indicators of exposure to organic (e.g., PAHs and PCBs) and inorganic (e.g., $\mathrm{Cu})$ contaminants.

Other physiological changes in mussels exposed to chemical contaminants have been observed, including reductions in growth rate (scope-for-growth), altered condition indices (Cappuzzo and Leavitt 1988; Widdows and Johnson 1988; Widdows et al. 1990), and impaired growth and reproductive success proportional to the exposure level of chemical contaminants (Salazar and Salazar 1991).

The degree to which the biomarkers of exposure in the digestive gland are responsive to seasonal impacts and variations is currently unknown. It is likely that cytochemical changes and their responsiveness to contaminant exposure may vary seasonally. It has already been established that wholeorganism responses to chemical contaminants may be strongly affected by seasonal conditions and seasonal variation (such as fluctuations in temperature, food availability, and reproductive status). Interpreting and attributing differences in organism responses to contaminants and to seasonal variation can be problematic. Previous field studies with mussels (Krishnakumar et al. 1994, 1995, 1997) could not address the potential interactive effect of these exogenous factors due to limited temporal sampling (mussels were only sampled at one time period)

The current study was completed to determine if seasonal variability affected the ability to use those cytochemcial parameters shown to be responsive to chemical contaminants throughout the year. Mussels were collected monthly from a reference nonurban site (Coupeville, Penn Cove) and a polluted urban site (Seacrest, Elliott Bay) in Puget Sound, WA. Physiological parameters known to vary with seasonal influences (Gosling 1992) were recorded. These included total length, total weight, somatic and mantle weights (an indication of gonadal development and reproductive status), and condition index. Hemic neoplasia (HN) was also sampled as a potential stressor that could influence biomarker response in mussels and could also be subject to seasonal variation. Lysosomal stability, NADPH-ferrihemoprotein reductase activity, lipofuscin deposition, and accumulation of lysosomal and cytoplasmic unsaturated neutral lipid were similarly measured monthly. In general, the differences in cytochemical responses between Coupeville and Seacrest mussels remained consistent over time despite seasonal fluctuations in the size, growth, condition index, and other related biological variables. These findings suggest that seasonal variability does not significantly influence biomarker results linked to contaminant exposure in mussels. 
Table 1. Shell length $(\mathrm{mm})$ and tissue wet weight $(\mathrm{g})$ of mussels, Mytilus edulis complex $(\mathrm{n}=25$ per month, per site) sampled from a nonurban reference site (Coupeville) and an urban polluted site (Seacrest) (values are means \pm SD)

\begin{tabular}{|c|c|c|c|c|c|c|}
\hline \multirow[b]{2}{*}{$\begin{array}{l}\text { Sampling } \\
\text { Date }\end{array}$} & \multicolumn{3}{|l|}{ Coupeville } & \multicolumn{3}{|l|}{ Seacrest } \\
\hline & Length & Somatic Weight & $\begin{array}{l}\text { Mantle (Gonad) } \\
\text { Weight }\end{array}$ & Length & Somatic Weight & $\begin{array}{l}\text { Mantle (Gonad) } \\
\text { Weight }\end{array}$ \\
\hline July 92 & $60 \pm 4.9$ & $4.9 \pm 1.4$ & $3.0 \pm 1.0$ & $46 \pm 3.9$ & $2.2 \pm 0.5$ & $1.2 \pm 0.5$ \\
\hline August 92 & $60 \pm 4.3$ & $5.4 \pm 0.9$ & $3.1 \pm 0.9$ & $43 \pm 2.8$ & $2.1 \pm 0.4$ & $1.0 \pm 0.2$ \\
\hline September 92 & $67 \pm 6.5$ & $6.1 \pm 1.5$ & $3.0 \pm 0.8$ & $47 \pm 5.1$ & $2.6 \pm 1.0$ & $1.2 \pm 0.7$ \\
\hline October 92 & $59 \pm 3.2$ & $4.7 \pm 2.5$ & $1.8 \pm 0.5$ & $39 \pm 1.7$ & $1.6 \pm 0.3$ & $0.6 \pm 0.1$ \\
\hline November 92 & $59 \pm 3.8$ & $4.0 \pm 1.5$ & $2.5 \pm 1.1$ & $38 \pm 2.9$ & $1.3 \pm 0.3$ & $0.5 \pm 0.1$ \\
\hline December 92 & $50 \pm 4.8$ & $2.6 \pm 1.5$ & $1.4 \pm 0.2$ & $37.9 \pm 2.6$ & $1.3 \pm 0.3$ & $0.4 \pm 0.1$ \\
\hline January 93 & $63 \pm 6.0$ & $4.5 \pm 2.0$ & $2.1 \pm 0.4$ & $38.6 \pm 3.3$ & $1.2 \pm 0.3$ & $0.4 \pm 0.1$ \\
\hline February 93 & $56 \pm 4.7$ & $3.7 \pm 1.5$ & $2.4 \pm 0.3$ & $37.8 \pm 2.0$ & $1.5 \pm 0.5$ & $0.6 \pm 0.1$ \\
\hline March 93 & not sampled & not sampled & not sampled & not sampled & not sampled & not sampled \\
\hline April 93 & $60 \pm 4.5$ & $7.8 \pm 2.2$ & $3.6 \pm 1.2$ & $42 \pm 4.0$ & $2.3 \pm 1.0$ & $1.3 \pm 0.5$ \\
\hline May 93 & $61 \pm 3.9$ & $7.2 \pm 1.4$ & $2.7 \pm 0.7$ & $38 \pm 4.1$ & $2.0 \pm 0.9$ & $0.8 \pm 0.6$ \\
\hline June 93 & $62 \pm 5.7$ & $4.7 \pm 1.2$ & $4.5 \pm 1.5$ & $38 \pm 2.4$ & $1.2 \pm 0.3$ & $1.4 \pm 0.4$ \\
\hline July 93 & $63 \pm 6.2$ & $4.4 \pm 1.2$ & $3.8 \pm 0.8$ & $37 \pm 2.8$ & $1.1 \pm 0.3$ & $1.1 \pm 0.4$ \\
\hline August 93 & $61 \pm 4.1$ & $5.0 \pm 1.1$ & $4.0 \pm 1.1$ & $39 \pm 3.2$ & $1.0 \pm 0.5$ & $1.5 \pm 0.5$ \\
\hline September 93 & $63 \pm 5.1$ & $5.5 \pm 1.7$ & $3.7 \pm 1.4$ & $41 \pm 3.6$ & $1.8 \pm 0.6$ & $1.1 \pm 0.5$ \\
\hline
\end{tabular}

\section{Materials and Methods}

\section{Collection}

Mussels (M. edulis complex) (McDonald et al. 1991) were collected monthly from their natural beds at two sites in Puget Sound (Figure 1) from July 1992-September 1993. The first site was Seacrest, on Elliott Bay, which is an urban area of high boat traffic and industrial activity. Sediment from Seacrest contains elevated concentrations of PAHs and PCBs (Stein et al. 1992). High levels of these contaminants are known to bioaccumulate in the tissues of mussels at this site $(>500 \mathrm{ng} / \mathrm{g}$ dry weight of PAHs and PCBs) (Krishnakumar et al. 1994). The second site was a nonurban reference site located at Coupeville, on Whidbey Island, WA. Mussels from Coupeville have relatively low tissue concentrations of PAHs and PCBs $(<100 \mathrm{ng} / \mathrm{g}$ dry weight $)$ and served as controls in studies examining the extent of biological impairment in mussels from urban estuaries (Krishnakumar et al. 1994). Following collection, mussels were depurated for $24 \mathrm{~h}$ in a flow-through seawater system at the Mukilteo Field Station, a National Marine Fisheries Service Facility located in Mukilteo, WA. Depuration facilitates the removal of any residual sediments in the soft tissues or body cavity. Following depuration, 35 mussels per site per month were analyzed (10 for cytochemical responses and 25 for biological measurements).

\section{Biology}

Barnacles and byssal threads, which can interfere with accurate measurements, were removed from the surface of mussels taken for biological analyses $(n=25)$. Length (umbo to farthest posterior margin), total weight, wet and dry weights for somatic and gonadal tissue, and sex were recorded for each mussel. This information was used to determine the condition indices. Condition indices normalize biological changes over time and can serve as an indication of the influence of seasonal fluctuations of reproductive status on biological measurements. They can also help assess the role of environmental factors, such as temperature and food availability, on the physiological status of bivalves. Length condition index (BCI $[\ln ]$ ) was calculated as follows: BCI $(\mathrm{ln})=$ tissue $w t(\mathrm{~g}) /$ shell length $(\mathrm{mm}) \times 100$.

The disease HN (or leukemia) is a biological parameter that is believed to influence the cytochemical parameters in mussels. To determine the prevalence of $\mathrm{HN}, 0.2-0.5 \mathrm{ml}$ of hemolymph was drawn from the posterior adductor muscle of 20 mussels per month per site. Hemolymph was collected with a 23-gauge needle into a 3-cc syringe containing $0.5 \mathrm{ml}$ Tris-EDTA hemocyte buffer (Krishnakumar et al. 1999). The contents of the syringe were then placed on a poly-L-lysine slide in a moist chamber and incubated at room temperature for 30 min. After incubation the slides were fixed in methanol and stained using the Schiff-Feulgen picromethyl blue procedure (Farley 1969) and then microscopically examined for the presence or absence of $\mathrm{HN}$, as described by Elston et al. (1988).

\section{Cytochemical Parameters}

A section of the digestive gland was removed from 10 randomly selected mussels per site per month (Krishnakumar et al. 1994, 1995). Five tissue sections were placed in straight rows across the center of each cryomold (Tissue-Tek, Miles, Elkhart, IN). The molds were placed in a slurry of liquid nitrogen cooled $\left(-70^{\circ} \mathrm{C}\right)$ hexane and embedded in OCT compound (Optimum Cutting Temperature, TissueTek). The resulting frozen blocks were stored at $-80^{\circ} \mathrm{C}$ until stained. For staining, blocks were placed in a cryostat at $-20^{\circ} \mathrm{C}$ and $10-\mu \mathrm{m}$ serial sections were cut. These sections were affixed to room-temperature slides and stained for each of the biomarker assays as described later. To ensure impartial results, all samples were randomly coded prior to analyses and decoded only after all measurements were made.

Duplicate neutral lipid sections from each cryomold, totaling 10 individual mussel samples per site per month, were prepared according to methods described in Bancroft (1967). Briefly, the samples were rinsed in distilled water and placed in $60 \%$ triethyl phosphate $(\mathrm{v} / \mathrm{v}$ with distilled water) for $3 \mathrm{~min}$ and stained in a $1 \%$ solution of Oil Red O (Sigma, St Louis, MO) for $15 \mathrm{~min}$. Sections were then washed and rinsed and mounted with glycerol gelatin (Sigma) under a coverslip for analyses. The slides were then examined using automated image analysis.

Samples for lipofuscin (degraded lipoprotein) analysis were also prepared in duplicate. The slides were fixed for $10 \mathrm{~min}$ in calciumformal at $4^{\circ} \mathrm{C}$, rinsed, and stained using the Schmorl reaction (Pearse 1972). Following staining in a solution of ferric chloride and potassium ferricyanide the slides were rinsed and mounted under coverslips 


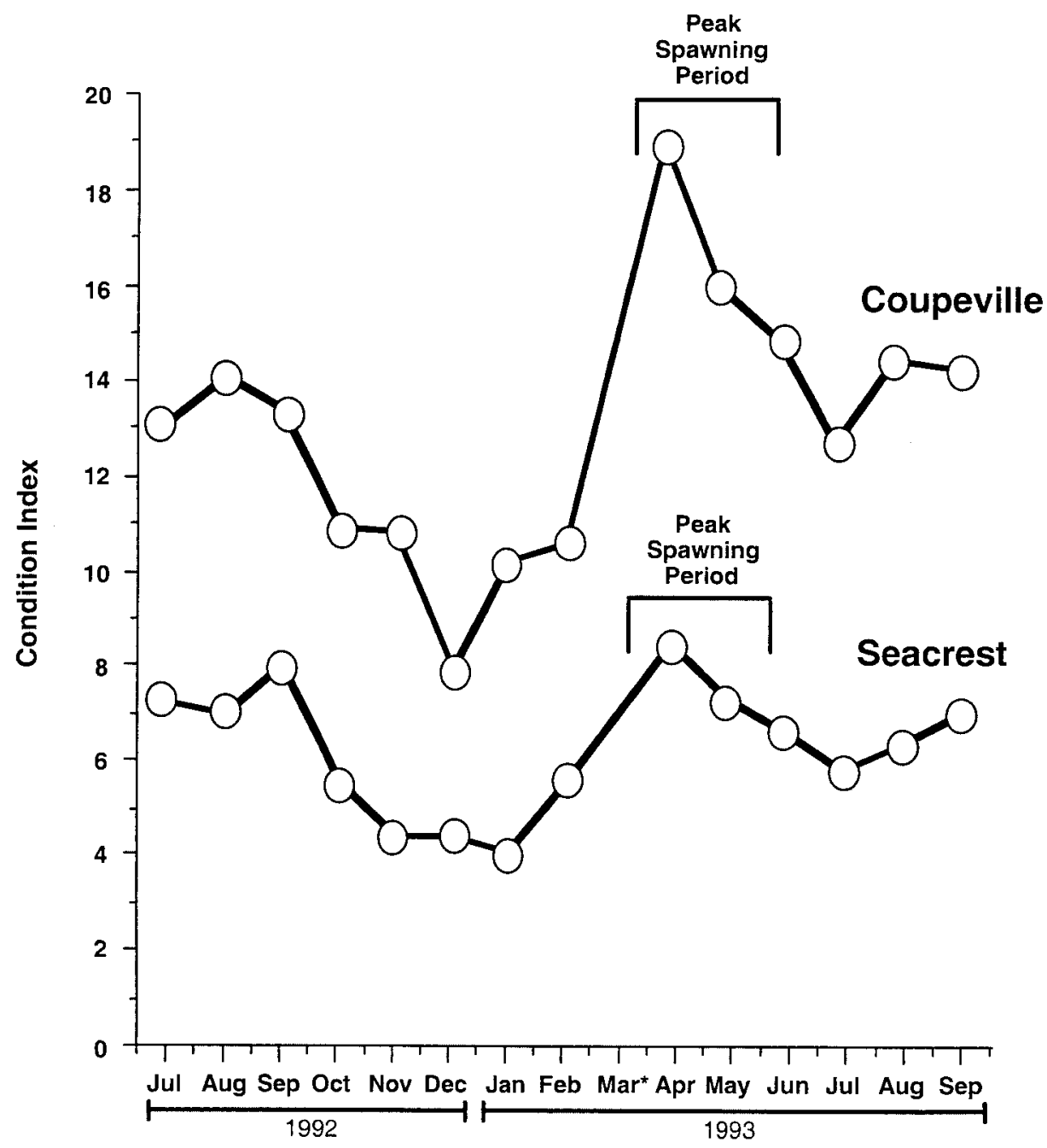

* No mussels were sampled in March, 1993
Fig. 2. Changes in the condition index of mussels (Mytilus edulis complex) from Coupeville and Seacrest $(n=25$ per site, per month) from July 1992 to September 1993. The condition index is the somatic tissue wet weight $(\mathrm{g}) /($ shell length $[\mathrm{mm}]) * 100$
Table 2. The prevalence of hemic neoplasia in mussels (Mytilus edulis complex) from a nonurban reference site (Coupeville) and an urban polluted site (Seacrest) during monthly sampling April-September, 1993 (20 mussels were sampled during each month from each site)

\begin{tabular}{lll}
\hline Sampling Date & Coupeville $(\%)$ & Seacrest $(\%)$ \\
\hline April 93 & 15 & 12 \\
May 93 & 25 & 30 \\
June 93 & 30 & 39 \\
July 93 & 35 & 11 \\
August 93 & 15 & 11 \\
September 93 & 30 & 25 \\
\hline
\end{tabular}

using glycerol gelatin. The slides were then analyzed using image analyses.

Lysosomal stability, or labilization period (the time necessary to labilize the responsive fraction of lysosomal hydrolase in an acid buffer), was determined using the marker enzyme N-acetyl B-hexosaminidase (Bitensky et al. 1973; Moore 1988). Multiple sections for each tissue sample were incubated at $37^{\circ} \mathrm{C}$ in a citrate buffer contain- ing $\mathrm{NaCl}$ to labilize the lysosomal membrane. Serial sections were then allowed to labilize for exposure time periods of $0,2,5,10,15,20$, 25 , and $30 \mathrm{~min}$. After each time point sections were incubated for 20 min at $37^{\circ} \mathrm{C}$ in a reaction medium consisting of napthol AS-BI Nacetyl b-D-glucosamide (Sigma) dissolved in 2-methoxy ethanol and citrate buffer with $\mathrm{NaCl}$ and low-viscosity polypeptides (Sigma). Sections were then rinsed, placed in phosphate buffer, and stained with fast violet B (Sigma) at room temperature. After being stained for 10 min, the samples were fixed for $15 \mathrm{~min}$ in chilled calcium-formal, rinsed, and mounted with glycerol gelatin and a coverslip. The maximum reaction product for $\mathrm{N}$-acetyl B-hexosaminidase (NAH) enzyme activity, corresponding to lysosomal activity, was then determined. This was accomplished by using automatic image analysis to examine the different levels of reaction product in the slides, recorded as pixel density, from the various incubation times.

NADPH-ferrihemoprotein reductase activity (NFR) is the detoxifying enzyme in bivalves similar in function to cytochrome P-450 in fish species. This enzyme reaction product was stained using the methods of Van Noorden and Butcher (1986) and Moore (1988). Duplicate cryomold tissue sections were incubated in total darkness for $30 \mathrm{~min}$ at $37^{\circ} \mathrm{C}$ in a sealed, oxygen-free atmospheric nitrogen chamber. The incubation medium consisted of $0.1 \mathrm{M}$ HEPES buffer, $20 \mathrm{mM} \mathrm{MgCl}$ (hexahydrate), $18 \%$ polyvinyl alcohol, 5 mM NADPH, 1\% dimethyl 


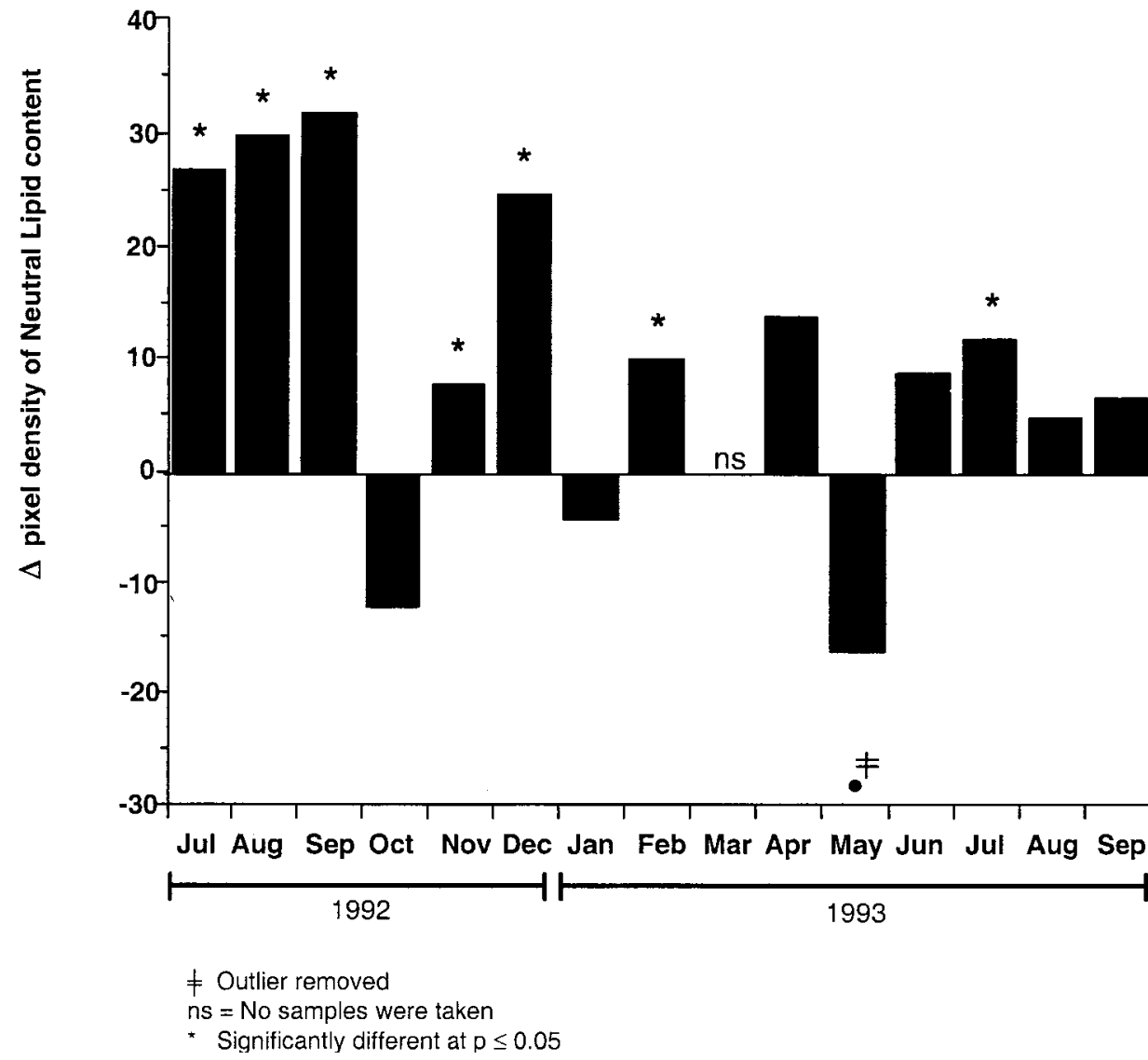

Fig. 3. Differences $(\Delta)$ in neutral lipid content (Seacrest mussel pixel density minus Coupeville mussel pixel density) from July 1992 to September 1993. Values for each month represent the average neutral lipid content of the digestive cells of Mytilus edulis complex ( $\mathrm{n}=10$ per site, per month) from Coupeville and Seacrest measured as pixel density taken from image analysis

formamide, $1 \% \mathrm{ETOH}$, and $0.005 \mathrm{M}$ neotetrazolium chloride. Following incubation, sections were rinsed twice in running and distilled water, respectively, and mounted using glycerol gelatin. Blank (background) values were determined by staining duplicate sections in a medium containing $1 \mathrm{mM}$ NADP + . NFR enzyme activity is completely inhibited (55\% to $69 \%$ inhibition) by $5 \mathrm{mM}$ NADP + . The finished slides were then examined by automatic image analysis for overall pixel density.

\section{Image Analysis}

Tissue sections were quantitatively assessed for each of the cytochemical biomarkers (neutral lipid, lipofuscin, reductase, and lysosomal stability) using computer-enhanced automatic image analysis according to Krishnakumar et al. (1994). The system included a highresolution charged couple device (CCD) color camera (COHU, mod. 8215.2000) mounted on a light microscope. Image analysis software (NIH v. 1.49) electronically captured the microscopic images displayed on a television screen and stored them on a Macintosh computer. Image intensity, or pixel density, was measured using a 255-unit gray scale $(0=$ absolute white and $255=$ true black $)$ with a $40 \times$ objective. Ten images of digestive tubules from the digestive gland were randomly taken from each duplicate section for each mussel (10 mussels per site per month). All images for each assay from both sites for each month were captured within a single day, during which all microscopic illumination and camera settings were kept constant. The digital image consisted of an eight-bit, $320 \times 240$ matrix of pixel bits. Average pixel densities were then calculated from the reaction products in the stored computer images. For each cytochemical reaction, a predetermined standard lower threshold level was used to separate reaction products from background values. The software program automatically converted the original image to a threshold picture, which is used to calculate the average gray value of the image. A mean pixel density was then determined for each individual mussel for every parameter measured.

\section{Statistics}

Differences in lysosomal responses, size, and condition indices of mussels between the two sites sampled monthly were tested using an unpaired single-tailed $t$-test (Zar 1984). The results shown in the figures are modified to represent the difference in the mean biomarker values of the reference site (Coupeville) subtracted from the contaminated site (Seacrest) at each monthly sampling point. The significance level for all statistical tests was set at $\mathrm{p} \leq 0.05$.

\section{Results}

Biology

Mussel length remained consistent throughout the sampling period, mean lengths for mussels from Coupeville (the nonurban reference site) ranged from 50-67 $\mathrm{mm}$ and $37-47 \mathrm{~mm}$ in mussels from Seacrest (the urban polluted site) (Table 1) Although the length of collected mussels did not vary markedly over the sampling period at each site, there was an increase in somatic and mantle weight during the peak spawning period 


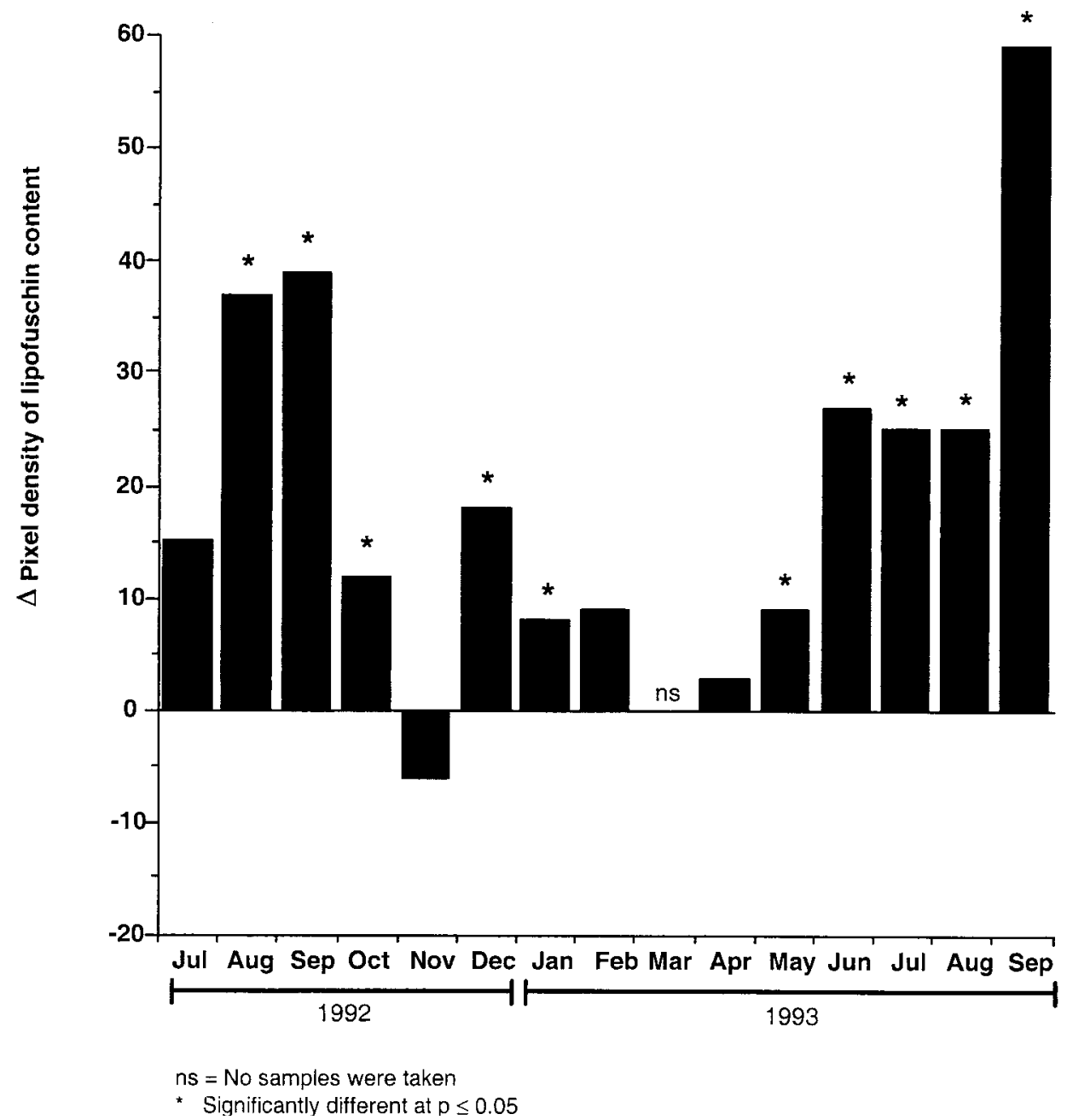

Fig. 4. Differences $(\Delta)$ in lipofuscin content (Seacrest mussel pixel density minus Coupeville mussel pixel density) from July 1992 to September 1993. Values for each month represent the average lipofuscin content of the digestive cells of Mytilus edulis complex ( $\mathrm{n}=10$ per site, per month) from Coupeville and Seacrest measured as pixel density taken from image analysis
(April-May) compared to the other months. The mean somatic weight of the mussels from Coupeville ranged from 7.2-7.8 g during the peak spawning period (April-May) and was only 2.6-6.1 $\mathrm{g}$ for all the other months sampled. The mantle weight of the mussels also displayed a similar pattern. The mean somatic weight of mussels was 2.0-2.3 g from Seacrest for the spawning period and 1.0-2.2 $\mathrm{g}$ for the remaining months (excluding an unusually high value of $2.6 \mathrm{~g}$ for September 1992). The condition index mirrored these changes. There was an increase in the condition index of mussels from both sites during the peak spawning period, with the highest increase in mussels from Coupeville (Figure 2).

Over a 6-month period from April 1993 to September 1993, we examined 20 mussels each month from each site for HN (or leukemia). HN was found in mussels collected from both Coupeville and Seacrest (Table 2). Prevalence ranged from $15-30 \%$ in mussels from Coupeville and $11-39 \%$ in mussels from Seacrest. Although mussels from Seacrest did display the highest prevalence of 39\% in June 1993, mussels from Coupeville showed a generally higher prevalence when comparing mussels between the sites during each monthly sampling. In fact, the prevalence of neoplasia in mussels was higher at Coupeville in 4 out of the 6 months sampled. The relationship between the prevalence of hemic neoplasia and site was not found to be significantly different using chi-square analysis at $\mathrm{p} \leq 0.05$.

\section{Cytochemical Parameters}

Generally, either there were no significant differences in the various parameters tested between mussels from Coupeville or these mussels were more similar to each other than to mussels from Seacrest over time. Similarly, there were no significant temporal differences in the various parameters tested among mussels from Seacrest.

Monthly sampling of mussels from Seacrest from July 1992 through September 1993 generally (but not always) showed an increase in neutral lipid and lipofuscin content, increased NFR activity, and decreased lysosomal stability in the digestive cells when compared to levels found in mussels from Coupeville (Figures 3-6).

The mean ( $\mathrm{n}=10$ per month per site) neutral lipid content of all the mussels from Coupeville was $65 \pm 26$ compared to $73 \pm 18$ (measured as pixel density taken from image analysis) for mussels from Seacrest. Neutral lipid levels in digestive cells of mussels from Seacrest were significantly higher than those 


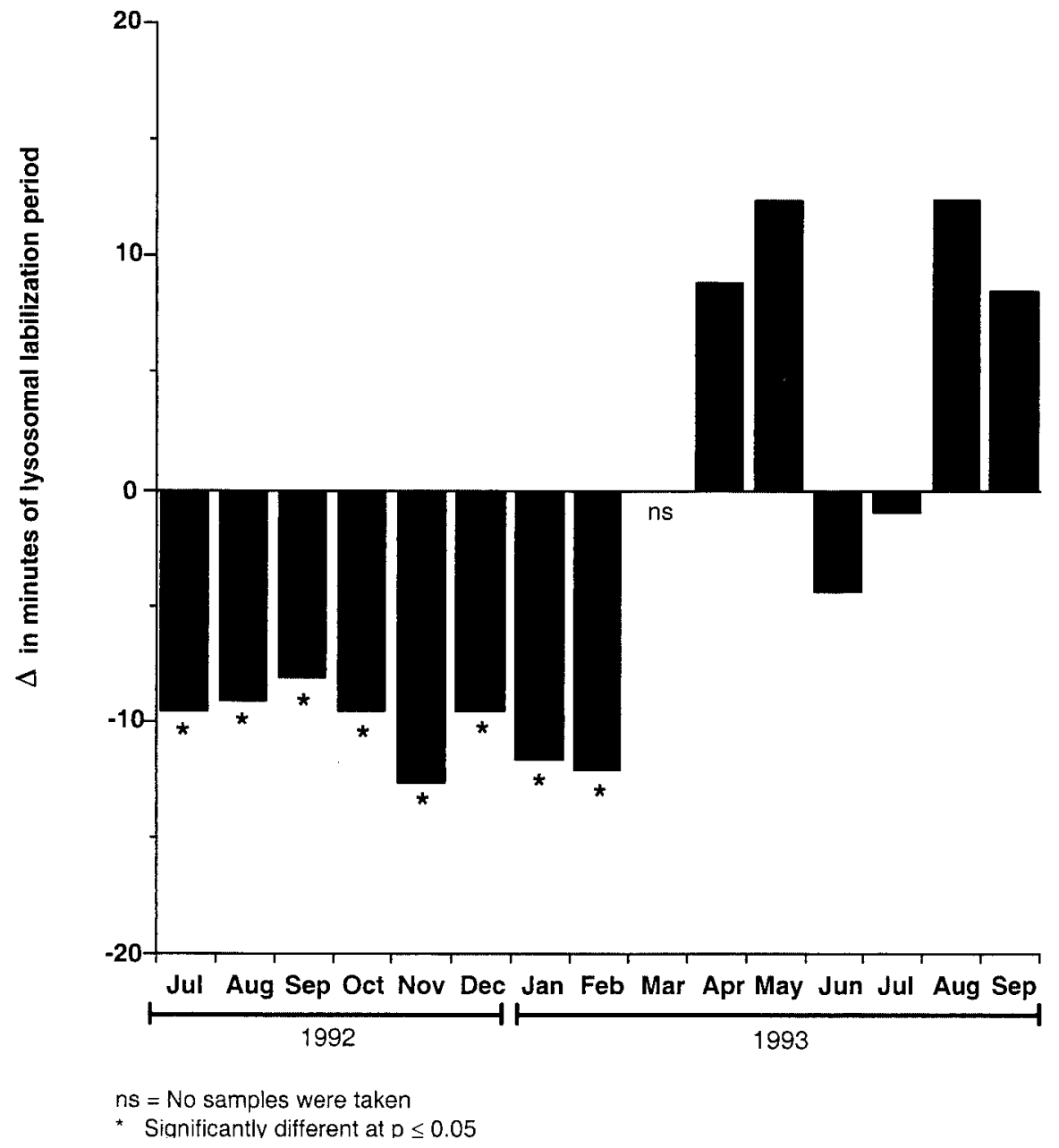

Fig. 5. Differences $(\Delta)$ in lysosomal stability (the labilization time in min of Seacrest mussels minus the labilization time in min of Coupeville mussels) from July 1992 to September 1993. Values represent the average lysosomal labilization period of five mussels (Mytilus edulis complex) per month per site measured in minutes taken from image analysis

for mussels from Coupeville for 7 months and higher (but not significantly) for an additional 4 months over the 14 months sampled. This relationship was reversed in October and January 1992 and again in May 1993, a peak spawning month for mussels in Puget Sound, WA (Figure 3).

The average lipofuscin content of the mussels from Coupeville and Seacrest was $49 \pm 19$ and $69 \pm 24$, respectively. Lipofuscin pixel density in mussels from Seacrest was significantly higher than in mussels from Coupeville for 10 of the 14 sampling months (Figure 4). Lipofuscin levels for mussels from Seacrest were lower than those for mussels from Coupeville for only one out of the 14 months sampled.

The mean lysosomal labilization period for mussels from Coupeville was $17 \pm 5.0 \mathrm{~min}$, whereas for Seacrest mussels the labilization period was $13 \pm 6.0 \mathrm{~min}$. The lysosomal stability was significantly shorter for Seacrest mussels than for corresponding mussels from Coupeville in over half $(57 \%)$ of the months sampled and a shorter period overall in 10 of the 14 months (Figure 5). In April and May (periods of high spawning activity) and the last two months of 1993, the lysosomal labilization period was longer for mussels from Seacrest.

Similarly, NFR activity was significantly higher in mussels from Seacrest when compared to mussels from Coupeville for 4 of the 6 months in which data were available (Figure 6). Reductase levels in April, though not significant, also followed this trend. The only time this relationship was not evident was in June. In fact, the average reductase content in the mussel digestive cells from Coupeville was $60 \pm 20$ pixels, whereas NADPH activity was on average measured as $76 \pm 20$ pixels for mussels from the contaminated Seacrest site.

The trend indicated in each of the parameters above was even more evident when viewed together as a suite (Table 3 ). For example, when three biomarkers were considered together for the first eight months of the study, two or more exhibited a similar trend between the two sites to results documented previously in Krishnakumar et al. (1994, 1995). When all four biomarkers were available for the final 6 months, the same trend was exhibited in these parameters $75 \%$ of the time.

\section{Discussion}

Seasonal variations in physiological systems and digestive gland enzymes used as indicators of cellular alteration in mussels has been observed (Viarengo et al. 1991). The purpose of this study was to determine if seasonal variability would confound interpretation of the responses of cytochemical parameters in mussels that can be used to assess exposure to contaminants. This study revealed that the differences in cytochemical 


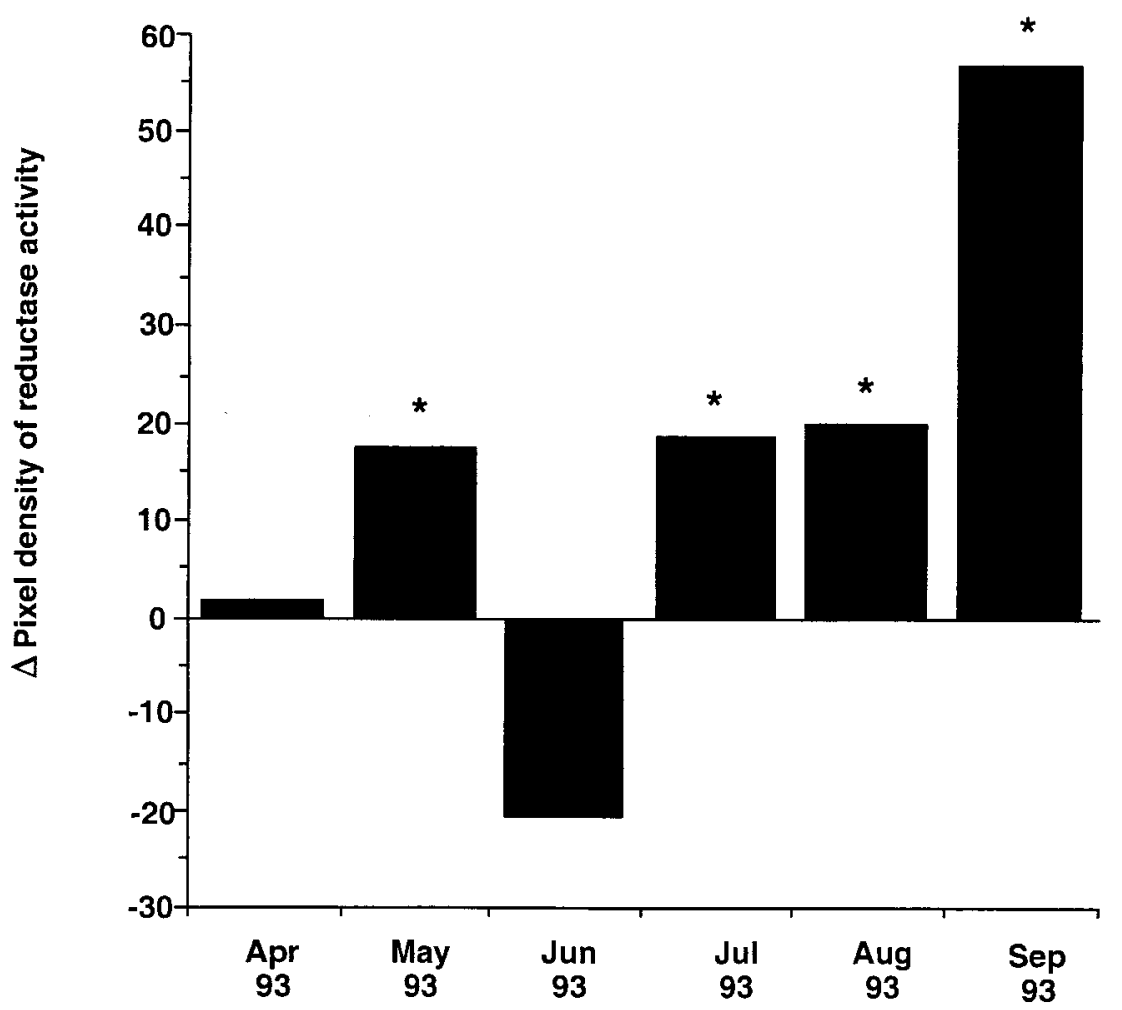

* Significantly different at $p \leq 0.05$
Fig. 6. Differences $(\Delta)$ in NAD$\mathrm{PH}$-ferrihemoprotein reductase activity (Seacrest mussel pixel density minus Coupeville mussel pixel density) from April 1993 to September 1993. Values for each month represent the average reductase content of the digestive cells of Mytilus edulis complex ( $\mathrm{n}=10$ per site, per month) from Coupeville and Seacrest measured as pixel density taken from image analysis and corrected for background

Table 3. Seasonal differences in the responses of a suite of biomarkers in Mytilus edulis complex

\begin{tabular}{|c|c|c|c|c|c|c|}
\hline Month & $\begin{array}{l}\text { Neutral } \\
\text { Lipid }\end{array}$ & Lipofuscin & $\begin{array}{l}\text { Lysosomal } \\
\text { Stability }\end{array}$ & $\begin{array}{l}\text { NADPH } \\
\text { Reductase }\end{array}$ & $\begin{array}{l}\text { Total } \\
\text { SD }^{\mathrm{a}}\end{array}$ & $\begin{array}{l}\text { Total } \\
\text { Trend }\end{array}$ \\
\hline July 92 & $+*$ & + & $-*$ & NA & 2 & 3 \\
\hline August 92 & $+*$ & $+*$ & $-*$ & NA & 3 & 3 \\
\hline September 92 & $+*$ & $+*$ & $-*$ & NA & 3 & 3 \\
\hline October 92 & - & $+*$ & $-*$ & NA & 2 & 2 \\
\hline November 92 & $+*$ & - & $-*$ & NA & 2 & 2 \\
\hline December 92 & $+*$ & $+*$ & $-*$ & NA & 3 & 3 \\
\hline January 93 & - & $+*$ & $-*$ & NA & 2 & 2 \\
\hline February 93 & $+*$ & + & $-*$ & NA & 2 & 3 \\
\hline March 93 & NA & NA & NA & NA & NA & NA \\
\hline April 93 & + & + & + & + & 0 & 3 \\
\hline May 93 & - & $+*$ & + & $+*$ & 2 & 2 \\
\hline June 93 & + & $+*$ & - & - & 1 & 3 \\
\hline July 93 & $+*$ & $+*$ & - & $+*$ & 3 & 4 \\
\hline August 93 & + & $+*$ & + & $+*$ & 2 & 3 \\
\hline September 93 & + & $+*$ & + & $+*$ & 2 & 3 \\
\hline$\%$ trends $\mathrm{SD}^{\mathrm{c}}$ & 50 & 71 & 57 & 66 & 93 & \\
\hline
\end{tabular}

Values are expressed as positive $(+)$ or negative $(-)$ by comparing biomarker responses in mussels from Seacrest to biomarker responses in mussels from Coupeville ( $\mathrm{n}=10$ per site, per month).

* Significantly different at $\mathrm{p} \leq 0.05$ (one-tailed).

${ }^{a}$ Total number of biomarker responses in mussels that were significantly different between the sites.

b Total number of biomarker responses that displayed a similar trend between the two sites to results documented previously in Krishnakumar $e t$ al. $(1994,1995)$.

${ }^{\mathrm{c}}$ Percentage of individual biomarker responses that displayed a similar trend between the two sites to results documented previously in Krishnakumar et al. $(1994,1995)$ and were significantly different.

responses between mussels from the reference (Coupeville) and contaminated (Seacrest) sites generally remained consistent over time. Although each of the cytochemical parameters in mussels from Seacrest were not always significantly different from mussels from Coupeville, they were significant in over half the time points sampled for every parameter exam- 
ined, which is consistent with previous research efforts (Krishnakumar et al. 1994, 1995, 1997). Statistically, some of the individual parameters (such as lysosomal stability) were weakest during April-June, a period of gonadal development and spawning activity. This may be related to energy spent on reproduction, which is normally dedicated to resisting the effects of chemical contaminants during other periods of the mussel life cycle. It is important to note, however, that although individual biomarker responses may not remain significant during peak spawning activity, the general trend between biomarker response from the two sites remains. Moreover, there has long been demand to consider combining cytochemical tests as a suite (Moore 1985, 1990) when they are applied in the field of environmental monitoring. When considered as a suite of parameters, at least one (and often two or more) of the parameters indicated exposure to chemical contaminants in mussels sampled from Seacrest when compared with mussels from Coupeville at all sampling times (Table 3). This indicates that seasonal variability does not appear to entirely suppress the ability of a suite of bioindicators to serve as indicators of contaminant exposure in mussels from urban sites, despite seasonal fluctuations influencing the condition index and other whole-organism indices in the mussels sampled.

The influence of seasonal variability on mussel physiology was most clearly observed as an increase in the condition index and to a lesser extent an increase in the somatic and mantle tissue weights from both sites during peak spawning periods (Figure 2). Coupeville mussels had the most dramatic increases in somatic weight and the largest peak of the condition index during spawning (Table 1). This suggests that mussels from nonreference sites are able to devote more energy to reproduction when environmental conditions are favorable.

In addition to gonadal development, the prevalence of $\mathrm{HN}$ may also confound the use of the cytochemical parameters as measures of chemical contaminant exposure. Previous research (Krishnamkumar et al. 1999) showed that HN did not vary in response to chemical contaminant exposure; however, it was not determined whether HN could alter the response of cytochemical parameters to contaminant exposure. HN can infect a high proportion of mussels in Puget Sound and could therefore be a confounding factor in interpreting the results. Although mussels from Seacrest did display the single highest prevalence of $\mathrm{HN}$ at an individual time point, mussels from Coupeville had a higher prevalence in 4 out of the 6 months sampled (Table 2). There was no apparent seasonal variation in the prevalence of $\mathrm{HN}$ within each of these populations. Because the values of $\mathrm{HN}$ observed from both sites did not change consistently with seasonal variations, $\mathrm{HN}$ is not likely to have variably affected the response of the parameters measured in mussels from this study.

As mentioned, differences in the four biomarkers of cytochemical responses between the reference and contaminated mussels generally remained consistent over time. When considered as a suite of biomarkers, rather than independently, this trend becomes clearer (Table 3). For example, significant differences between mussels from the two sites was only apparent $50 \%, 57 \%, 66 \%$, and $71 \%$ of the time for the neutral lipid, lysosomal stability, NADPH reductase, and liposfuscin biomarkers, respectively. Yet when all four assays are considered together as a combined monitoring suite, the significant differences in at least one biomarker response between mussels from the two sites is over $92 \%$. Similarly, when comparing mussels from the two sites for trends that are similar to those found previously (Krishnakumar et al. 1994, 1995), values ranged from 71-93\%, depending on the individual parameter. When viewed as a suite, at least one of the three or four biomarkers assessed always (100\%) revealed differences in cytochemical responses to contaminant exposure between mussels from the two sites during every month sampled, irrespective of season.

In summary, neutral lipid, liposfuscin, lysosomal stability, and NFR are cytochemically derived measures of subcellular and cellular events and, when applied as a suite of measures, can be used during any season to assess contaminant exposure in mussels despite fluctuations in physiological conditions. These findings support the continued use of this selected suite of parameters in field monitoring and laboratory research programs to determine the effects of contaminants in bivalves.

Acknowledgments. The authors are thankful to Kyle Kardong for assistance in field collections and biological measurements, Dave Misitano and Frank Sommers for maintaining the animals at the field station, Tom Hom for statistical assistance, and Herb Sanborn for technical assistance.

\section{References}

Axiak V, George JJ, Moore MN (1988) Petroleum hydrocarbons in the marine bivalve Venus verrucosa: accumulation and cellular responses. Mar Biol 97:225-230

Bancroft JD (1967) An introduction to histochemical technique. Butterworths, London

Bayne BL (1989) Measuring the biological effect of pollution: the mussel watch approach. Wat Sci Technol 21:1089-1100

Bayne BL, Clarke KR, Gray GS (1988) Biological effects of pollutants: the results of a practical workshop. Mar Ecol Prog Ser $46: 1-5$

Bitensky L, Butcher RS, Chayen J (1973) Quantitative cytochemistry in the study of lysosomal function. In: Dingle JT (ed) Lysosomes in biology and pathology, vol 3. Elsevier, Amsterdam, pp 465 510

Cajaraville MP, Marigomez JA, Anulo E (1989) A stereological survey of lysosomal structure alterations in Littorina littorea exposed to 1-naphtol. Comp Biochem Physiol 93C:231-237

Cappuzzo JM, Leavitt DF (1988) Lipid composition of the digestive glands of Mytilus edulis and Carcinus maenas in response to pollutant gradients. Mar Ecol Prog Ser 46:139-145

Elston RA, Kent ML, Drum AS (1988) Progression, lethality and remission of hemic neoplasia in the bay mussel Mytilus edulis. Dis Aquat Org 4:135-142

Farley CA (1969) Probable neoplastic disease of the hematopoietic system in oysters, Crassostrea virginica and Crassostrea gigas. Natl Cancer Inst Monogr 31:541-555

Farrington JW, Goldberg ED, Risebrough RW, Martin JJ, Bowen VT (1983) US "Mussel Watch" 1976-1978: an overview of the trace-metal, DDE, PCB, hydrocarbon, and artificial radionuclide data. Environ Sci Technol 17:490-496

Goldberg ED, Koide M, Hodge V, Flegal AR, Martin J (1983) U.S. Mussel Watch: 1977-1978 results on trace metals and radionuclides. Est Coast Shelf Sci 16:69-93

Gosling E (ed) (1992) The mussel Mytilus: ecology, physiology, genetics and culture. Develop Aquacult Fish Sci 25 
Gray JS (1992) Biological and ecological effects of marine pollutants and their detection. Mar Pollut Bull 25:48-50

Krishnakumar PK, Asokan PK, Pillai VK (1990) Physiological and cellular responses to copper and mercury in the green mussel Perna viridis (Linnaeus). Aquat Toxicol 18:163-174

Krishnakumar PK, Casillas E, Varanasi U (1994) Effects of chemical contaminants on the health of Mytilus edulis from Puget Sound, Washington, USA I. Cytochemical measures of lysosomal responses in the digestive cells using automatic image analysis. Mar Ecol Prog Ser 106:249-261

Krishnakumar PK, Casillas E, Varanasi U (1995) Effects of chemical contaminants on the health of Mytilus edulis from Puget Sound, Washington, II. Cytochemical detection of subcellular changes in digestive cells. Mar Biol 124:251-259

Krishnakumar PK, Casillas E, Varanasi U (1997) Cytochemical responses in the digestive tissue of Mytilus edulis complex exposed to microencapsulated PAHs or PCBs. Comp Biochem Physiol $118 \mathrm{C}(1): 11-18$

Krishnakumar PK, Casillas E, Snider RG, Kagley AN, Varanasi U (1999) Environmental contaminants and the prevalence of hemic neoplasia (leukemia) in the common mussel (Mytilus edulis complex) from Puget Sound, Washington, U.S.A. J Invertebr Pathol 73:135-146

Lauenstein GG (1988) The NOAA National Status and Trends Mussel Watch program. J Shellfish Res 7(3):569

Lauenstein GG (1995) Comparison of organic contaminants found in mussels and oysters from a current mussel watch project with those from archived mollusc samples from the 1970s. Mar Pollut Bull 30(12):826-833

Lauenstein GG, Dolvin SS (1992) Mollusk monitoring of United States coastal and estuarine environments. Analusis 20(6):M23M26

Livingston DR (1991) Organic xenobiotics metabolism in marine invertebrates. In: Giles R (ed) Advances in comparative and environmental physiology. Springer-Verlag, Berlin, pp 45-185

Lowe DM, Moore MN, Clarke KE (1981) Effect of oil on digestive cells in mussels: quantitative alterations in cellular and lysosomal structure. Aquat Toxicol 1:213-226

McDonald JH, Seed R, Koehn RK (1991) Allozymes and morphometric characters of three species of Mytilus in the Northern and Southern Hemispheres. Mar Biol 111:323-333

Moore MN (1985) Cellular responses to pollutants. Mar Pollut Bull 16(4):134-139

Moore MN (1988) Cytochemical responses of the lysosomal system and NADPH-ferrihemoprotein reductase in molluscan digestive cells to environmental and experimental exposure to xenobiotics. Mar Ecol Prog Ser 46:81-89

Moore MN (1990) Lysosomal cytochemistry in marine environmental monitoring. Editorial review. Histochem J 22:187-191

Moore MN (1991) Environmental distress signals: cellular reactions to marine pollution. Prog Histochem Cytochem 23:2-19

Moore MN, Clarke KR (1982) Use of microstereology and quantitative cytochemistry to determine the effects of crude oil-derived aromatic hydrocarbons on lysosomal structure and function in a marine bivalve mollusc, Mytilus edulis. Histochem J 14:713-718

Moore MN, Mayernick JA, Giam CS (1985) Lysosomal responses to a polynuclear aromatic hydrocarbon in marine snail: effects of exposure to phenanthrene and recovery. Mar Environ Res 17: $230-233$

NOAA (National Oceanic and Atmospheric Administration) (1989)
National Status and Trends Program for marine environmental quality: a summary of data on tissue concentration from the first three years (1986-1988). Of the Mussel Watch project. NOAA Tech Memo NOS/OMA-49

Nott JA, Moore MN (1987) Effects of polycyclic aromatic hydrocarbons on molluscan lysosomes and endoplasmic reticulum. Histochem J 19:357-368

O'Connor T (1992) Recent trends in coastal environmental quality: results from the first five years of the NOAA Mussel Watch Project. NOAA, Department of Commerce, Silver Spring, MD

O'Connor TP, Lauenstein GG (1989) Ten-year trends in chemical contamination in mussels and oysters. J Shellfish Res 8(2):452

Pearse AGE (1972) Histochemistry, theoretical and applied, vol 2. Churchill-Livingstone, London

Pipe RK, Moore MN (1986) An ultrastructural study on the effect of phenanthrene on lysosomal membrane and distribution of the lysosomal enzyme b-glucuronidase in the digestive cells of the periwinkle L. littorea. Aquat Toxicol 8:65-76

Porte C, Sole M, Albaiges MJ, Livingstone DR (1991) Responses of mixed-function oxygenase and antioxidase enzyme system of Mytilus sp. to organic pollution. Comp Biochem Physiol 100C: 183-186

Pruell RJ, Quinn J, Lake JL, Davis WR (1987) Availability of PCBs and PAHs to Mytilus edulis from artificially resuspended sediments. In: Capuzzo JM, Kester DR (eds) Oceanic processes in marine pollution, vol 1: Biological processes and wastes in the ocean. Robert E. Kreiger, 10:97-108

Salazar MH, Salazar SM (1991) Assessing site specific effects of TBT contamination with mussel growth rates. Mar Environ Res 32: $131-150$

Stein JE, Collier TK, Reichert, WL, Casillas E, Hom T, Varanasi U (1992) Bioindicators of contaminant exposure and sublethal effects: studies with benthic fish in Puget Sound, Washington. Environ Toxicol Chem 11:701-714

Van Noorden DJF, Butcher RG (1986) Enzyme reaction rate studies in electromotor neurons of the weakly electric fish Apternotus leptorhynchus. Histochem J 21:609-671

Viarengo A, Canesi L, Pertica M, Livingstone DR (1991) Seasonal variations in the antioxidant defence systems and lipid peroxidation of the digestive gland of mussels. Comp Biochem Physiol $100 \mathrm{C}(1 / 2): 187-190$

Viarengo A, Moore MN, Pertica M, Mancinelli G, Accomando R (1992) A simple procedure for evaluating the protein degradation rate in mussel (M. galloprovincialis Lam.) tissues and its application in a study of phenanthrene effects on protein catabolism. Comp Biochem Physiol 103B:27-32

Widdows J, Johnson D (1988) Physiological energetics of Mytilus edulis: scope for growth. Mar Ecol Prog Ser 46:113-121

Widdows J, Burns KA, Menon NR, Page DS, Soria S (1990) Measurement of physiological energetics (scope for growth) and chemical contaminants in mussels (Arca zebra) transplanted along a contamination gradient in Bermuda. J Exp Mar Biol Ecol 138: 99-117

Winston GW, Moore MN, Straatsburg I, Kirchin MA (1991) Decreased stability of digestive gland lysosomes from the common mussel M. edulis L. by in vitro generation of oxygen free radicals. Arch Environ Contam Toxicol 21:401-408

Zar JH (1984) Biostatistical analysis. Prentice Hall, Englewood Cliffs, NJ 
Copyright of Archives of Environmental Contamination \& Toxicology is the property of Kluwer Academic Publishing / Academic and its content may not be copied or emailed to multiple sites or posted to a listserv without the copyright holder's express written permission. However, users may print, download, or email articles for individual use. 